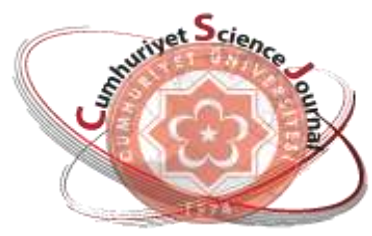

e-ISSN: $2587-246 X$

ISSN: $2587-2680$

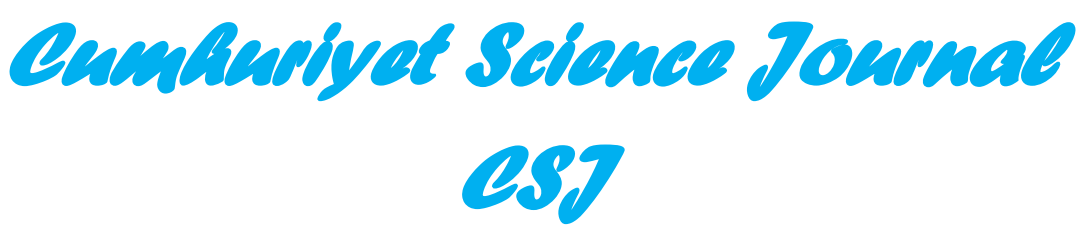

Cumhuriyet Sci. J., Vol.39-1(2018) 274-293

\title{
An Integrated TOPSIS, GRA and VIKOR Based on Interval Type-2 Fuzzy Method to Improve Customer Satisfaction in Public Transportation
}

\author{
Muhammet DEVECI \\ University of Yildiz Technical, 34349 Yildiz, Istanbul, TURKEY
}

Received: 31.10.2017; Accepted: 28.02.2018

http://dx.doi.org/10.17776/csj.347964

\begin{abstract}
Recently, multi-criteria decision making problems with interval type-2 fuzzy methods have received increasing attention both from researchers and practitioners. In this study, an interval type-2 fuzzy TOPSIS and GRA based VIKOR method is proposed for the evaluation of the customer satisfaction in all the transportation modes in Istanbul (metro, bus and bus rapid transit). Furthermore, the interval type-2 fuzzy TOPSIS method is also utilized to solve the problem. An online survey is conducted to investigate factors affecting public transport users' satisfaction with the service. Data is collected from 323 public transport users in Istanbul. As a result, an interval type-2 fuzzy multi-criteria decision making method has been proposed for the evaluation of customer satisfaction in public transportation. The performances of various multi-criteria decision making methods are also compared with each other with a view to exploring the effectiveness and flexibility of proposed method and interval type-2 fuzzy TOPSIS method. The results show that the proposed method is reliable and practical for evaluate problems and other MCDM problems.
\end{abstract}

Keywords: Customer satisfaction, Public transportation, Interval type-2 fuzzy multi criteria decision making, TOPSIS, GRA, VIKOR

\section{Toplu Taşımacılıkta Müşteri Memnuniyetini Geliştirmek için Aralıklı Tip- 2 Bulanık Yöntemini Temel Alan Bütünleşik Bir TOPSIS, GRA ve VIKOR}

\begin{abstract}
Özet: Son zamanlarda, aralıklı tip-2 yöntemleri ile çok kriterli karar verme problemleri hem araştırmacıların hem de uygulayıcıların dikkatini çekmiştir. Bu çalışmada, İstanbul'daki tüm taşıma modlarında (metro, otobüs ve metrobüs) müşteri memnuniyetinin değerlendirilmesi için bir aralıklı tip-2 bulanık TOPSIS ve GRA tabanlı VIKOR yöntemi önerilmiştir. Buna ek olarak, problemi çözmek için aralıklı tip-2 bulanık TOPSIS yöntemi de kullanılmaktadır. Toplu taşıma kullanıcılarının hizmet memnuniyetini etkileyen faktörleri araştırmak için bir online (çevrimiçi) anket yürütülmüştür. Veriler, İstanbul'da toplu taşıma kullanıcısı olan 323 kişiden toplanmıştır. Sonuç olarak, toplu taşımada müşteri memnuniyetinin değerlendirilmesi için bir aralıklı tip-2 bulanık çok kiriterli karar verme yöntemi önerilmiştir. Çeşitli çok kiriterli karar verme yöntemlerinin performansları, önerilen ve aralıklı tip-2 bulanık TOPSIS yöntemlerinin etkinliğini ve esnekliğini keşfetmek amacıyla birbiriyle karşılaştırılmıştır. Sonuçlar, önerilen yöntemin değerlendirme problemleri ve diğer MCDM problemleri için güvenilir ve pratik olduğunu göstermektedir.
\end{abstract}

Anahtar Kelimeler: Müşteri memnuniyeti, Toplu taşıma,Aralıklı tip-2 bulanık çok kriterli karar verme, TOPSIS, GRA, VIKOR

\footnotetext{
* Corresponding author.Email address: muhammetdeveci@gmail.com, mdeveci@yildiz.edu.tr http://dergipark.gov.tr/csj C2016 Faculty of Science, Cumhuriyet University
} 


\section{INTRODUCTION}

As urbanization rapidly spreads across the world, transportation becomes more important as an intermediary service required for economic, social and cultural activities [1]. Performance of the urban transportation systems affects directly the economic and social lives of people living in the cities [2]. Due to the rapid population increase and urban growth, solving transportation issues has the highest priority in terms of importance in local government of Istanbul. In this respect, public transit systems play the most crucial role in supporting urban mobility. Capacity-related problems and inadequacies of the public transport services create serious problems for the service sector. Cities with ineffective public transportation systems face serious transportation problems that cannot be solved easily.

Urban public transportation has become more important today, as most of the policy makers have acknowledged that using private vehicles cause serious social and economic problems. In Turkey, urban transportation issues affect one out of two persons directly and all citizens indirectly through the allocation of resources [3]. Transportation investments have impacts on the entire city. Thus, the quality of public transportation systems is of critical importance for the people living in Turkey, as elsewhere in the world.

Public transport systems with sufficient capacity can reduce the private car use and relieve traffic congestion. It also helps protect the environment by reducing $\mathrm{CO}_{2}$ emissions from numerous vehicles [4]. In addition to this, sustainable public transportation systems create more sustainable and livable cities by lowering the accident rates, providing increased urban mobility for all socioeconomic groups and reducing fuel consumption [5].
Since public transportation is a service presented to the customers, what is more important is how customers perceive the quality of service presented. To measure this, customer satisfaction surveys are conducted to learn the degree of satisfaction which is the indicator of perceived quality of service. Therefore, to improve the service quality in public transportation, results of customer satisfaction surveys play an important role. Since Istanbul's public transportation system is mainly composed of bus, bus rapid transit (BRT) and metro services, learning how customers percieve their comparative service quality is also important to understand different transport modes' effectiveness in delivering high quality service.

The purpose of this study is to describe the application of three Multi-Criteria Decision Making (MCDM) methods to evaluate and improve customer satisfaction of public transportation in Istanbul. An integrated VIKOR together with TOPSIS and GRA based on interval type-2 fuzzy are the three methods utilized to evaluate the customer satisfaction in all the transportation modes in Istanbul (metro, bus and BRT). MCDM methods provide the means to solve such problems supporting decision makers with the best option from a set of alternatives.

When we look at the results of the customer satisfaction survey (CSS), the satisfaction levels are ranked as follows: Metro > Buses > BRT. The criteria according to which the customers evaluated their satisfaction levels include: availability, accessibility, time, information, customer service, comfort, safety, environmental impact. 


\section{BACKGROUND}

In this section, we provide an overview of previous work in public transportation about customer satisfaction. The customer satisfaction problem involves considering many conflicting factors. Therefore, in this kind of decision problems, the techniques that will take into account all of the evaluation factors into assessment process should be used. In order to solve these kind of problems, multi-criteria decision making techniques are developed. MCDM is a decision method that involves the selection of the best option from a set of alternatives according to more than one factor depending on the condition of decision makers [613]. Decision making tools are widely adopted for public transportation area especially in customer satisfaction [14-15], sustainability [16], policy management and strategic planning [17-18] and performance evaluation [19-20].

There have been an extended or interval type- 2 fuzzy VIKOR (IT2FV) methods developed for a variety of problems such as location selection problem [21-22], maintenance strategy [23], robot selection [24], project investment evaluation problem [25], supplier evaluation [26-27], material selection [28-29], evaluating university faculty for tenure and promotion [30].

\section{METHODOLOGY}

In this study, we have applied interval type-2 fuzzy TOPSIS (IT2FT) based MCDM method. Their performances are compared to decide which one to use for the transportation modes in Istanbul. The proposed methodology consists of six stages. The stages of the proposed methodology for the evaluation of public transportation firms are shown in Fig. 1. The stages are as follows:

Stage 1: Identification of the criteria, alternatives and linguistic variables to be used in the model

Stage 2: Analysis of survey using these selected criteria, alternatives and linguistic variables

Stage 3: Analysis of Fuzzy TOPSIS (IT2FT) method ve and the positive ideal solution and negative ideal solution calculated in the $8^{\text {th }}$ step of this stage are used as input to Fuzzy GRA, Stage 4.

Stage 4: Calculation of Fuzzy GRA steps.

Stage 5: Analysis of Fuzzy VIKOR (IT2FV) method

Stage 6: Ranking each alternative for proposed methods based on the outcomes from Stage 3 and Stage 5. 


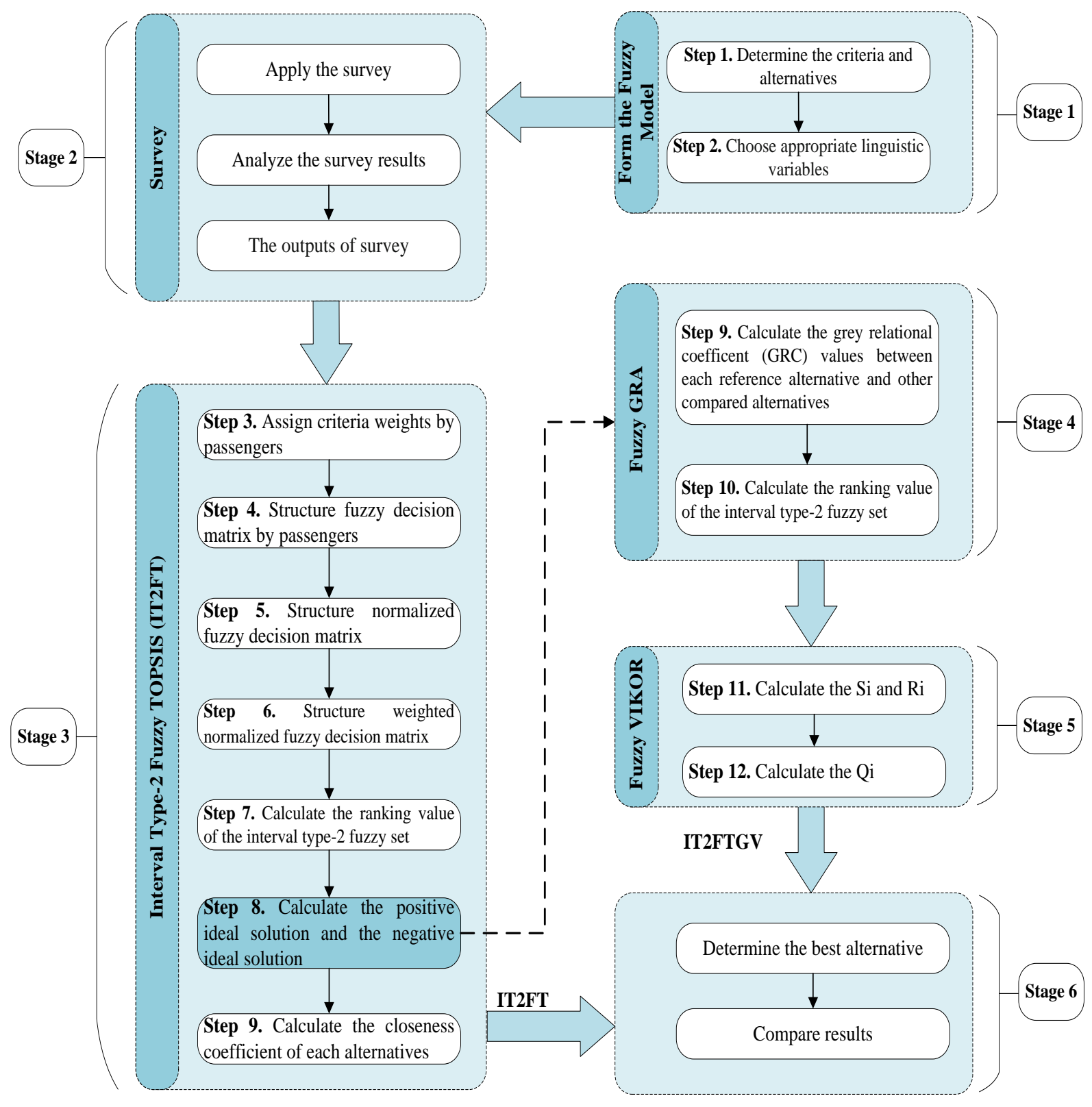

Figure 1. The steps of the proposed methodology.

\subsection{Form the Fuzzy Model and Survey}

Step 1. Determine criteria and alternatives. Let us assume that there is a set $\mathrm{A}$ of alternatives, where $A=\left\{a_{1}, a_{2}, \ldots, a_{n}\right\}$, and assume that there is a set $\mathrm{X}$ of criteria, $X=\left\{x_{1}, x_{2}, \ldots, x_{m}\right\}$. Form a committee of decision-makers. Assume that there are $k$ decision-makers $D M_{1}, D M_{2}, \ldots$, and $D M_{k}$. Each decision-maker is a participant in our questionnaire and has his own importance weight on each criterion, and he also has his own rating on alternatives in terms of each criterion. 
Step 2. Criteria and current alternatives are determined. Linguistic variables (see Table 1) are selected for DMs to evaluate the alternatives and determine the criteria weights.

Table 1. Linguistic variables for the importance weight of each criterion and rating scales [31].

\begin{tabular}{lll}
\hline Linguistic variables & Interval type-2 fuzzy sets & Linguistic variables \\
\hline Very low (VL) & $((0,0,0,0.1 ; 1,1),(0,0,0,0.05 ; 0.9,0.9))$ & Very poor (VP) \\
Low (L) & $((0,0.1,0.1,0.3 ; 1,1),(0.05,0.1,0.1,0.2 ; 0.9,0.9))$ & Poor (P) \\
Medium low (ML) & $((0.1,0.3,0.3,0.5 ; 1,1),(0.2,0.3,0.3,0.4 ; 0.9,0.9))$ & Medium poor (MP) \\
Medium (M) & $((0.3,0.5,0.5,0.7 ; 1,1),(0.4,0.5,0.5,0.6 ; 0.9,0.9))$ & Fair (F) \\
Medium high (MH) & $((0.5,0.7,0.7,0.9 ; 1,1),(0.6,0.7,0.7,0.8 ; 0.9,0.9))$ & Medium good (MG) \\
High (H) & $((0.7,0.9,0.9,1 ; 1,1),(0.8,0.9,0.9,0.95 ; 0.9,0.9))$ & Good (G) \\
Very high $(\mathrm{VH})$ & $((0.9,1,1,1 ; 1,1),(0.95,1,1,1 ; 0.9,0.9))$ & Very good $(\mathrm{VG})$ \\
\hline
\end{tabular}

\subsection{Interval Type-2 Fuzzy TOPSIS (IT2FT)}

The TOPSIS (Technique for Order Preference by Similarity to an Ideal Solution) method was proposed for the first time for MCDM problems in 1981 [32]. The most remarkable characteristic of TOPSIS, which is a linear weighting method, is the identification of the best solution for the closest to the positive ideal and the furthest to the negative ideal [33]. The step of this method is as follows:

Step 3. Fuzzy weights of each criterion and alternative are calculated using the equations numbered (1) and (2). " $k$ " in the equation corresponds to the number of decision makers.

$$
\begin{gathered}
\widetilde{\mathrm{w}}_{\mathrm{i}}=\frac{1}{\mathrm{~K}}\left[\widetilde{\widetilde{w}}_{i}^{1}(+) \widetilde{\widetilde{w}}_{i}^{2}(+) \ldots(+) \widetilde{\widetilde{w}}_{i}^{K}\right], \\
\mathrm{i}=1,2, \ldots, \mathrm{m} \text { (criteria) } \\
\tilde{\mathrm{x}}_{\mathrm{ij}}=\frac{1}{\mathrm{~K}}\left[\tilde{\tilde{x}}_{i j}^{1}(+) \tilde{\tilde{x}}_{i j}^{2}(+) \ldots(+) \tilde{\tilde{x}}_{i j}^{K}\right], \\
\mathrm{j}=1,2, \ldots, \mathrm{n} \text { (alternatives) }
\end{gathered}
$$

$\tilde{\tilde{x}}_{\mathrm{ij}}$ is the degree of " $\mathrm{i}$ "th criterion according to “j”th alternative and $\widetilde{\widetilde{w}}_{\mathrm{i}}$ is the significance weight of "i"th criterion (where $\widetilde{\widetilde{w}}_{i}^{K}$ and $\tilde{\tilde{x}}_{i j}^{K}$ are the rating and the significance weight of the $k$ th decision maker).

Step 4. The fuzzy decision matrix is determined as in the following (Eqs. (3-4)):

$$
A_{z}=\left(\tilde{x}_{i j}^{z}\right)_{m \times n}=\begin{gathered}
x_{1} \\
x_{2} \\
\vdots \\
x_{m}
\end{gathered}\left[\begin{array}{cccc}
\tilde{x}_{11}^{z} & \tilde{\tilde{x}}_{12}^{z} & \cdots & \tilde{\tilde{x}}_{11}^{z} \\
\tilde{\tilde{x}}^{z} & \tilde{\tilde{x}}_{22}^{z} & \cdots & \tilde{\tilde{x}}_{2 n}^{z} \\
\vdots & \vdots & \vdots & \vdots \\
\tilde{\tilde{x}}_{m 1}^{z} & \tilde{\tilde{x}}_{m 2}^{z} & \cdots & \tilde{\tilde{x}}_{m n}^{z}
\end{array}\right]
$$

and

$$
W_{z}=\left(\begin{array}{cccc}
x_{1} & x_{2} & \ldots & x_{m} \\
\left.\widetilde{\widetilde{w}}_{i}^{y}\right)_{1 \times m}=\left[\begin{array}{llll}
\widetilde{\widetilde{w}}_{1}^{y}, & \widetilde{\widetilde{w}}_{2}^{y}, & \ldots, & \widetilde{\widetilde{w}}_{m}^{y}
\end{array}\right]
\end{array}\right.
$$

where $\tilde{\tilde{x}}_{i j}=\left(\frac{\tilde{\tilde{x}}_{i}^{1} \oplus \tilde{\tilde{x}}_{i}^{2} \ldots \oplus \tilde{\tilde{x}}_{i}^{k}}{\mathrm{k}}\right), \tilde{\tilde{a}}_{i}$ is an interval type2 fuzzyset or crisp number, $1 \leq i \leq m, 1 \leq j \leq n, l$ $\leq y \leq k$ and denotes the number of decisionmakers.

where $\tilde{\tilde{x}}_{i j} \forall \mathrm{i}, \mathrm{j}$ and $\widetilde{\mathrm{w}}_{\mathrm{i}} ; \mathrm{i}=1,2, \ldots, \mathrm{m}$ (criteria) are linguistic variables which can be described by interval type-2 fuzzy numbers, $\tilde{\tilde{x}}_{\mathrm{ij}}=$ $\left(a_{i 1}^{U}, a_{i 2}^{U}, a_{i 3}^{U}, a_{i 4}^{U}\right)$ and $\widetilde{\widetilde{w}}_{\mathrm{i}}=\left(w_{i 1}^{U}, w_{i 2}^{U}, w_{i 3}^{U}, w_{i 4}^{U}\right)$, $\tilde{\tilde{x}}_{\mathrm{ij}}=\left(a_{i 1}^{L}, a_{i 2}^{L}, a_{i 3}^{L}, a_{i 4}^{L}\right) \quad$ and $\quad \widetilde{\widetilde{w}}_{\mathrm{i}}=$ $\left(w_{i 1}^{L}, w_{i 2}^{L}, w_{i 3}^{L}, w_{i 4}^{L}\right)$. 
Step 5. Normalize the fuzzy decision matrix.

$$
\begin{aligned}
& \tilde{\tilde{R}}=\left[\tilde{\tilde{r}}_{i j}\right]_{m x n} \quad i=1,2, \ldots, m ; j 1,2, \ldots, n \\
& \tilde{\tilde{r}}_{i j}=\left(\left(\frac{a_{i 1}^{U}}{\mathrm{c}_{\mathrm{j}}^{*}}, \frac{a_{i 2}^{U}}{\mathrm{c}_{\mathrm{j}}^{*}}, \frac{a_{i 3}^{U}}{\mathrm{c}_{\mathrm{j}}^{*}}, \frac{a_{i 4}^{U}}{\mathrm{c}_{\mathrm{j}}^{*}} ; \mathrm{H}_{1}\left(\widetilde{\mathrm{A}}_{i}^{U}\right), \mathrm{H}_{2}\left(\widetilde{\mathrm{A}}_{i}^{U}\right)\right),\left(\frac{a_{i 1}^{L}}{\mathrm{c}_{\mathrm{j}}^{*}}, \frac{a_{i 2}^{L}}{\mathrm{c}_{\mathrm{j}}^{*}}, \frac{a_{i 3}^{L}}{\mathrm{c}_{\mathrm{j}}^{*}}, \frac{a_{i 4}^{L}}{\mathrm{c}_{\mathrm{j}}^{*}} ; \mathrm{H}_{1}\left(\widetilde{\mathrm{A}}_{1 i}^{L}\right), \mathrm{H}_{2}\left(\widetilde{\mathrm{A}}_{i}^{L}\right)\right)\right) \\
& \tilde{\tilde{r}}_{i j}=\left(\left(\frac{\mathrm{c}_{\mathrm{j}}^{-}}{a_{i 4}^{U}}, \frac{\mathrm{c}_{\mathrm{j}}^{-}}{a_{i 3}^{U}}, \frac{\mathrm{c}_{\mathrm{j}}^{-}}{a_{i 2}^{U}}, \frac{\mathrm{c}_{\mathrm{j}}^{-}}{a_{i 1}^{U}} ; \mathrm{H}_{1}\left(\widetilde{\mathrm{A}}_{i}^{U}\right), \mathrm{H}_{2}\left(\widetilde{\mathrm{A}}_{i}^{U}\right)\right),\left(\frac{\mathrm{c}_{\mathrm{j}}^{-}}{a_{i 4}^{L}}, \frac{\mathrm{c}_{\mathrm{j}}^{-}}{a_{i 3}^{L}}, \frac{\mathrm{c}_{\mathrm{j}}^{-}}{a_{i 2}^{L}}, \frac{\mathrm{c}_{\mathrm{j}}^{-}}{a_{i 1}^{L}} ; \mathrm{H}_{1}\left(\widetilde{\mathrm{A}}_{1 i}^{L}\right), \mathrm{H}_{2}\left(\widetilde{\mathrm{A}}_{i}^{L}\right)\right)\right) \\
& \mathrm{c}_{\mathrm{j}}^{*}=\max _{i}^{U}, j \in B \text { (benefit criteria) and } \mathrm{c}_{\mathrm{j}}^{-}=\min c_{i j}^{U}, j \in C(\text { cost criteria). }
\end{aligned}
$$

Where $\mathrm{B}$ and $\mathrm{C}$ are the sets of benefit criteria and cost criteria, respectively as in the following:
Step 6. Structure the weighted normalized matrix.

$$
\begin{aligned}
& \tilde{\tilde{v}}=\left[\tilde{\tilde{v}}_{\mathrm{ij}}\right]_{\mathrm{mxn}}, \quad \mathrm{i}=1,2, \ldots, \mathrm{m} ; \\
& \mathrm{j}=1,2, \ldots, \mathrm{n} \quad \text { where } \tilde{\tilde{v}}_{\mathrm{ij}}=\widetilde{\tilde{\mathrm{r}}}_{\mathrm{ij}}(.) \widetilde{\widetilde{\mathrm{w}}}_{\mathrm{i}}
\end{aligned}
$$

where $\tilde{\tilde{v}}_{\mathrm{ij}}$ denotes the weighted normalized interval type-2 fuzzy numbers.

Step 7. Based on Eq. (9) and Eq. (10), calculate the ranking value $\operatorname{Rank}\left(\tilde{\tilde{v}}_{i j}\right)$ of the interval type2 fuzzy set $\tilde{\tilde{v}}_{i j}$, where $1 \leq j \leq n$.

Step 8. Compute the distance of each alternative from fuzzy positive-ideal solution (FPIS, A*) $\mathrm{A}^{*}=\left(v_{1}^{*}, v_{1}^{*}, \ldots, v_{m}^{*}\right)$ and fuzzy negative-ideal solution (FNIS, $\mathrm{A}^{*}=\left(v_{1}^{-}, v_{1}^{-}, \ldots, v_{m}^{-}\right)$, respectively as in the following:

$$
\begin{aligned}
& \mathrm{v}_{i}^{*} \\
& =\left\{\begin{array}{l}
\max \left\{\operatorname{Rank}\left(\tilde{\tilde{v}}_{i j}\right)\right\}, i \leq j \leq n, \quad \text { if } f_{i} \in B \\
\min \left\{\operatorname{Rank}\left(\tilde{\tilde{v}}_{i j}\right)\right\} \quad i \leq j \leq n, \quad \text { if } f_{i} \in C
\end{array}\right.
\end{aligned}
$$

and

$$
\begin{aligned}
& \mathrm{v}_{i}^{-} \\
& = \begin{cases}\min \left\{\operatorname{Rank}\left(\tilde{\tilde{v}}_{i j}\right)\right\}, i \leq j \leq n, & \text { if } f_{i} \in B \\
\min \left\{\operatorname{Rank}\left(\tilde{\tilde{v}}_{i j}\right)\right\}, i \leq j \leq n, & \text { if } f_{i} \in C\end{cases}
\end{aligned}
$$

The distance $\left(d_{j}^{*}, d_{j}^{-}\right)$of each weighted alternative $j=1,2, \ldots, n$ from the fuzzy positiveideal solution (FPIS, $\tilde{A}^{*}$ ) and the fuzzy negative ideal solution (FNIS, $\tilde{A}^{-}$) is computed as follows:

$$
d_{j}^{*}=d\left(\tilde{v}_{0 j}^{*}, \tilde{v}_{i j}\right)=\sqrt{\left(\operatorname{Rank}\left(\tilde{v}_{i j}\right)-v_{i}^{*}\right)^{2}}
$$

$$
d_{j}^{-}=d\left(\tilde{v}_{0 j}^{-}, \tilde{\tilde{v}}_{i j}\right)=\sqrt{\left(\operatorname{Rank}\left(\tilde{\tilde{v}}_{i j}\right)-v_{i}^{-}\right)^{2}}
$$

Step 9. Calculate the closeness coefficient $C C\left(x_{j}\right)$ of each alternative.

$$
C C\left(x_{j}\right)=\frac{d^{-}\left(x_{j}\right)}{d^{-}\left(x_{j}\right)+d^{*}\left(x_{j}\right)}
$$

\subsection{Fuzzy Grey Relational Analysis (GRA)}

Gray relational analysis (GRA) can be used to capture correlations between a reference (desired) alternative in a system and other comparative alternatives [34-36]. The GRA method steps are given as follows [37-39]. The grey relational coefficient $\xi_{i j}$ is defined as;

$\xi_{i j}=\frac{\delta_{\min }+\zeta \delta_{\max }}{\delta_{i j}+\zeta \delta_{\max }}$ 
$\delta_{i j}=\left|r_{0 j}-r_{i j}\right|, \quad \delta_{\max }=\max \left(\delta_{i j}\right), \quad \delta_{\min }=$ $\min \left(\delta_{i j}\right)$, and $\zeta$ resolving coefficient $\zeta \in[0,1]$.

The grey relational grade $\gamma_{i}$ is estimated by the relation;

$\gamma_{i}=\sum_{j=1}^{n} w_{j} \xi_{i j}, \quad i=1 \ldots, m$

$$
\gamma\left(\tilde{\tilde{v}}_{0 j}^{\alpha}, \tilde{\tilde{v}}_{i j}\right)==\frac{\min _{i} \min _{j} d\left(\tilde{\tilde{v}}_{0 j}^{\alpha}, \tilde{\tilde{v}}_{i j}\right)+\zeta \max _{i} \max _{j} d\left(\tilde{\tilde{v}}_{0 j}^{\alpha}, \tilde{\tilde{v}}_{i j}\right)}{d\left(\tilde{\tilde{v}}_{0 j}^{\alpha}, \tilde{\tilde{v}}_{i j}\right)+\zeta \max _{i} \max _{j} d\left(\tilde{\tilde{v}}_{0 j}^{\alpha}, \tilde{\tilde{v}}_{i j}\right)}
$$

where $\alpha=*,-$, and $1 \leq j \leq n$, and $\zeta$ is the resolving coefficient $\zeta \in[0,1]$.

Step 10. Calculate the grey relational coefficient of each alternative from PIS and NIS using the following equation, respectively.

$$
\begin{aligned}
& d^{*}\left(x_{j}\right)=\sum_{i=1}^{m} \gamma\left(\tilde{\tilde{v}}_{0 j}^{x}, \tilde{\tilde{v}}_{i j}\right) \\
& d^{-}\left(x_{j}\right)=\sum_{i=1}^{m} \gamma\left(\tilde{\tilde{v}}_{0 j}^{-}, \tilde{\tilde{v}}_{i j}\right)
\end{aligned}
$$

\subsection{Integrated TOPSIS, GRA and VIKOR Method Based on Interval Type-2 Fuzzy Numbers (IT2FTGV)}

This study presents a technique for intervalvalued type-2 fuzzy MCDM based on integration of the concepts of TOPSIS, GRA and VIKOR (IT2FTGV). VIKOR (Vlsekriterijumska Optimizacija I Kompromisno Resenje) method is proposed by Opricovic [40] for the MCDM [41]. The step of this method is as follows:

Step 11. $S_{i}$ and $R_{i}$ values can be computed, respectively as below: where $w_{j}$ denotes the weight of the $j$ th criterion, $\sum_{j=1}^{n} w_{j}=1$

Step 9. After computing the positive ideal and negative ideal alternatives, this paper proposes to calculate the grey relational coefficient (GRC) values between each reference alternatives and other compared alternatives by concisely expressing as follows $[31,36,39]$.

$$
\begin{aligned}
& S_{i}=\sum_{j}^{n} \gamma\left(\tilde{\tilde{v}}_{0 j}^{\alpha}, \tilde{\tilde{v}}_{i j}\right) \\
& R_{i}=\max _{j} R_{i j} \text { and } R_{i j}=\gamma\left(\tilde{\tilde{v}}_{0 j}^{-}, \tilde{\tilde{v}}_{i j}\right)
\end{aligned}
$$

Where $i=1,2,3, \ldots, m ; j=1,2,3, \ldots, n$.

Step 12. According to the values of $S_{i}$ and $R_{i}$, we can compute the $Q_{i}$, by these relations:

$$
Q_{i}=v \frac{\left(S^{*}-S_{i}\right)}{\left(S^{*}-S^{-}\right)}+(1-v) \frac{\left(R_{i}-R^{*}\right)}{\left(R^{-}-R^{*}\right)}
$$

Where

$S^{*}=\max S_{i}, \quad S^{-}=\min S_{i}$,

$R^{*}=\stackrel{i}{\min } R_{i} \quad$ and $\quad R^{-}=\max R_{i}$

$S^{*}=$ refers to compromising majority rule

$R^{*}=$ refers to minimum individual regrets

$v=$ the criteria or maximum group benefit $(v=0.5)$

" $1-v$ " corresponds to individual regret value [42].

The last, rank the alternatives according to minimum "Q" value. $A_{1}$ is selected as the best 
alternative among the four alternatives because it has the lowest Q value.”

\section{CASE STUDY}

In this study, by examining the results of customer satisfaction survey using interval type-fuzzy multi-criteria decision making methods, the ways to improve the customer satisfaction rates (CSS) in Istanbul's public transportation are examined.

"EN 13816 European Standard for transportation - logistics and services - public passenger transport - service quality definition, targeting and measurement" is a widely used quality standard especially in European countries for increasing service quality in public transport services. IETT uses the criteria defined in this standard to increase its service quality. In the CSS, the following eight criteria are taken into account to evaluate the satisfaction levels [43]:

Availability: This criterion is about the extent of the service offered in terms of geography, time, frequency and transport mode

Accesibility: This criterion is about how easily the passengers access to the public transportation network. This is especially important for vulnerable groups like disabled people, elderly and children.

Time: This criterion is about the aspects of time relevant to the planning and execution of the service.

Information: This criterion is about how passengers can easily find information about the services including route information, schedule etc. More integrated information services covering all transportation modes are regarded as better.

Customer service: Customer care refers to the responsiveness of the services to the customer needs. Staff helpfulness, dealing well with customer complaints and suggestions affect the level of customer care.

Comfort: This criterion is mainly related to how customers can easily and conveniently use public transportation services. This is affected by the number of passengers inside the bus, airconditioning and noise levels, ergonomic factors of the vehicle etc.

Safety: This criterion is about the safety levels both in the buses and in the bus stops, stations, interchange stations etc.

Environmental impact: This refers to the environmental benefits or costs that the public transportation services cause. Using alternative energy sources reduces the carbon footprint. Metro services, for example, are better in terms of their environmental costs than diesel powered buses.

Table 2. Evaluation criteria.

\begin{tabular}{llc}
\hline & \multicolumn{1}{c}{ Criteria } & Criteria Type \\
\hline $\mathrm{C}_{1}:$ & Availability & Benefit \\
\hline $\mathrm{C}_{2}:$ & Accesibility & Benefit \\
\hline $\mathrm{C}_{3}:$ & Time & Benefit \\
\hline $\mathrm{C}_{4}:$ & Information & Benefit \\
\hline $\mathrm{C}_{5}:$ & Customer service & Benefit \\
\hline $\mathrm{C}_{6}:$ & Comfort & Benefit \\
\hline $\mathrm{C}_{7}:$ & Safety & Benefit \\
\hline $\mathrm{C}_{8}:$ & Environmental impact & Benefit \\
\hline
\end{tabular}

\subsection{Public transportation structure in Istanbul}

Public transportation systems in Istanbul cover a wide range of urban transport modes, including road, rail, and maritime modes. Road transport mode includes buses, minibuses, shuttle vehicles and taxis; rail transport covers metro, light rail, tramway and funicular; maritime transportation incorporates ships, sea buses and motorboats. The data for March 2016 indicate that there are $9,674,385$ road passenger journeys on average per day; 1,605,384 rail passenger journeys and 264,252 sea passenger journeys in Istanbul [43] 
(http://www.iett.gov.tr). The total number of journeys for all transport modes equals to $11,544,029$ on average per day. Considering the sheer volume of passengers, it is clear that

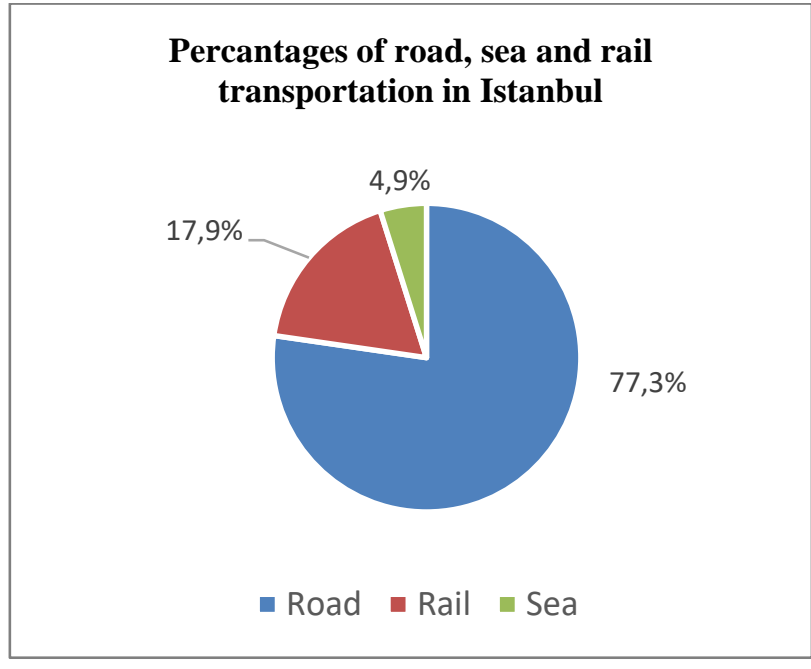

(a) Journey distribution by modes of transportation in Istanbul including land, maritime and rail transportation.

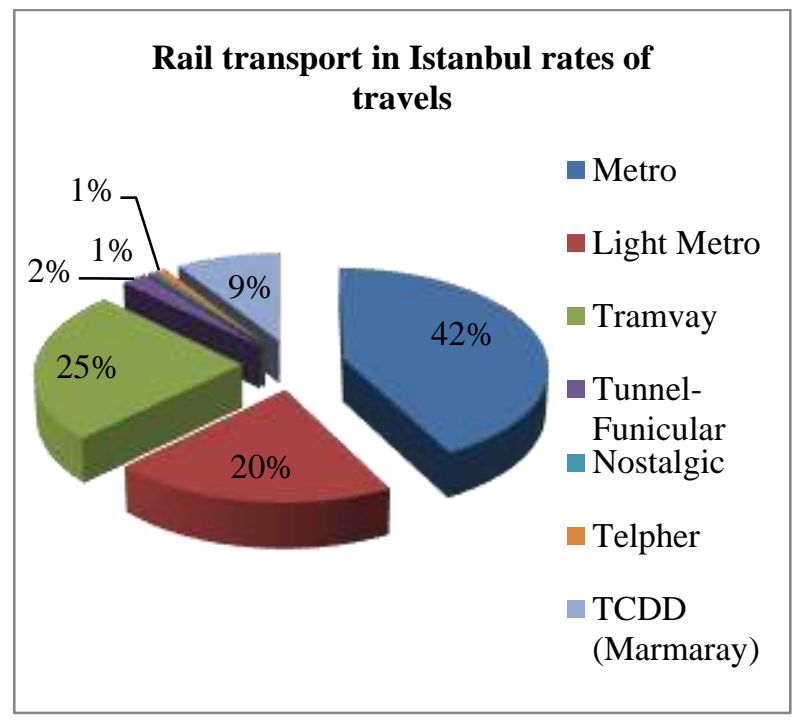

(c) Journeys by rail transportation in Istanbul. developing a customer oriented methodology to address urban transport issues will affect a quite large population.

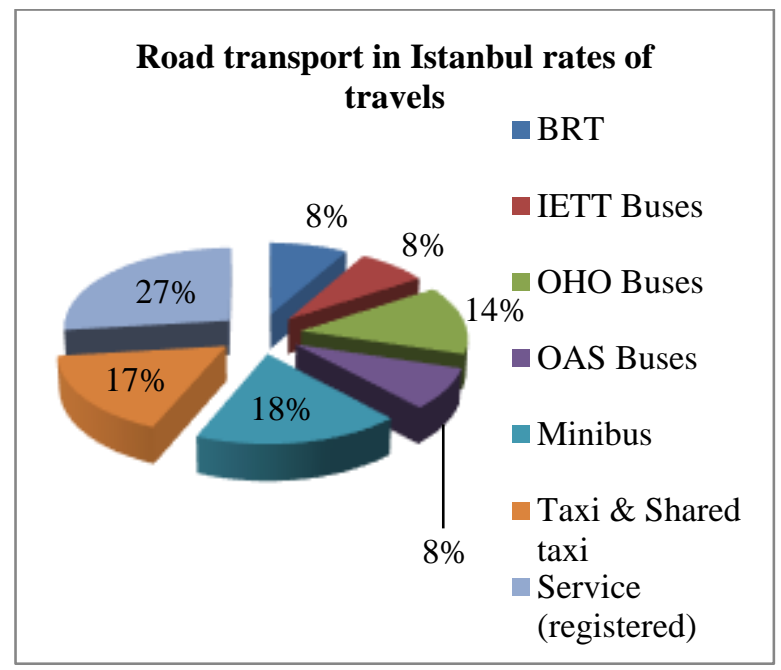

(b) Journeys by land transportation in Istanbul.

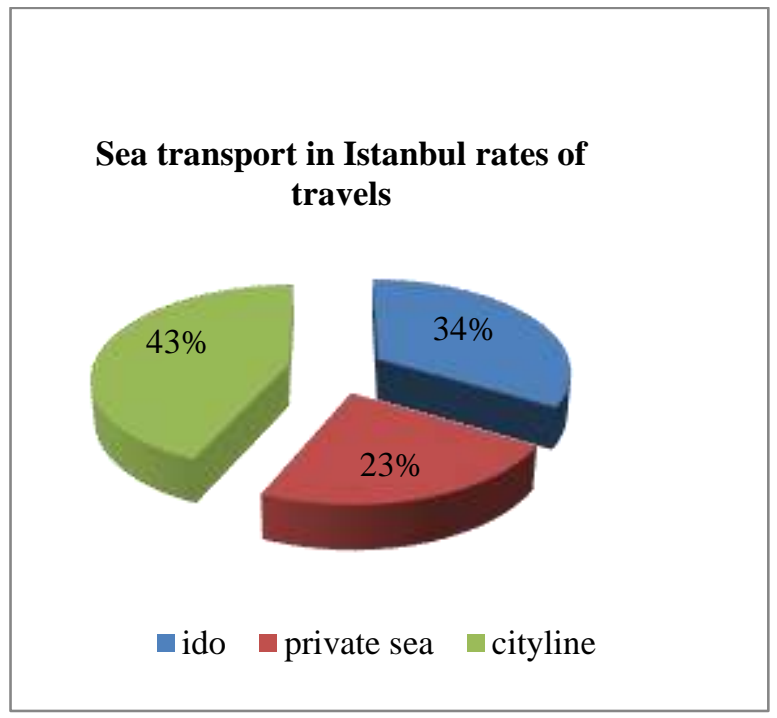

(d) Journeys by maritime transportation in Istanbul.

Figure 2. Journey distribution by modes of transportation in Istanbul including land, maritime and rail transportation.

In addition to this, Fig. 2 (a, b, c and d) shows the percentages of journey by modes of transportation including land, maritime and rail transportation [43] (http://www.iett.gov.tr). Meanwhile, as it is shown in the Fig. 3 and Fig. 4, the annual increase in IETT's (Istanbul Electricity, Tunnel and Tram Enterprises) bus and BRT operations reflect the increasing importance of this issue [44]: 


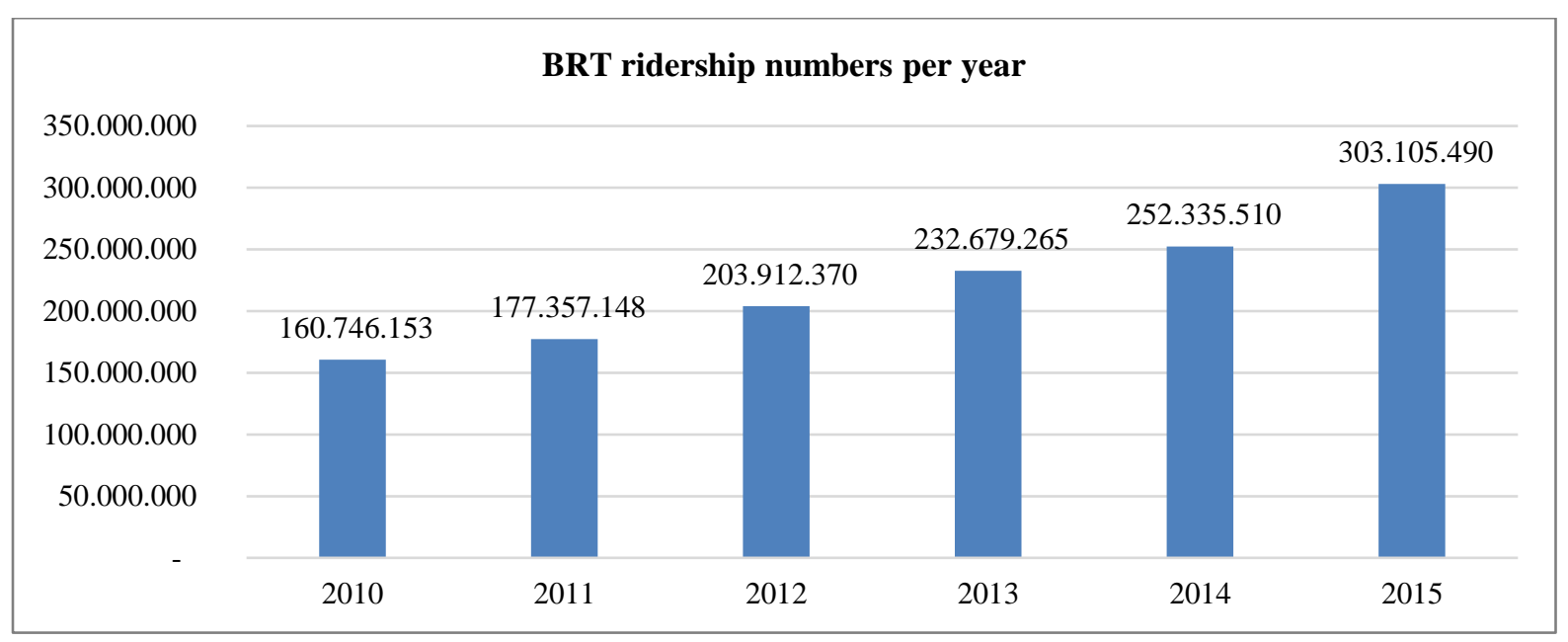

Figure 3. Number of IETT's BRT journeys by years.

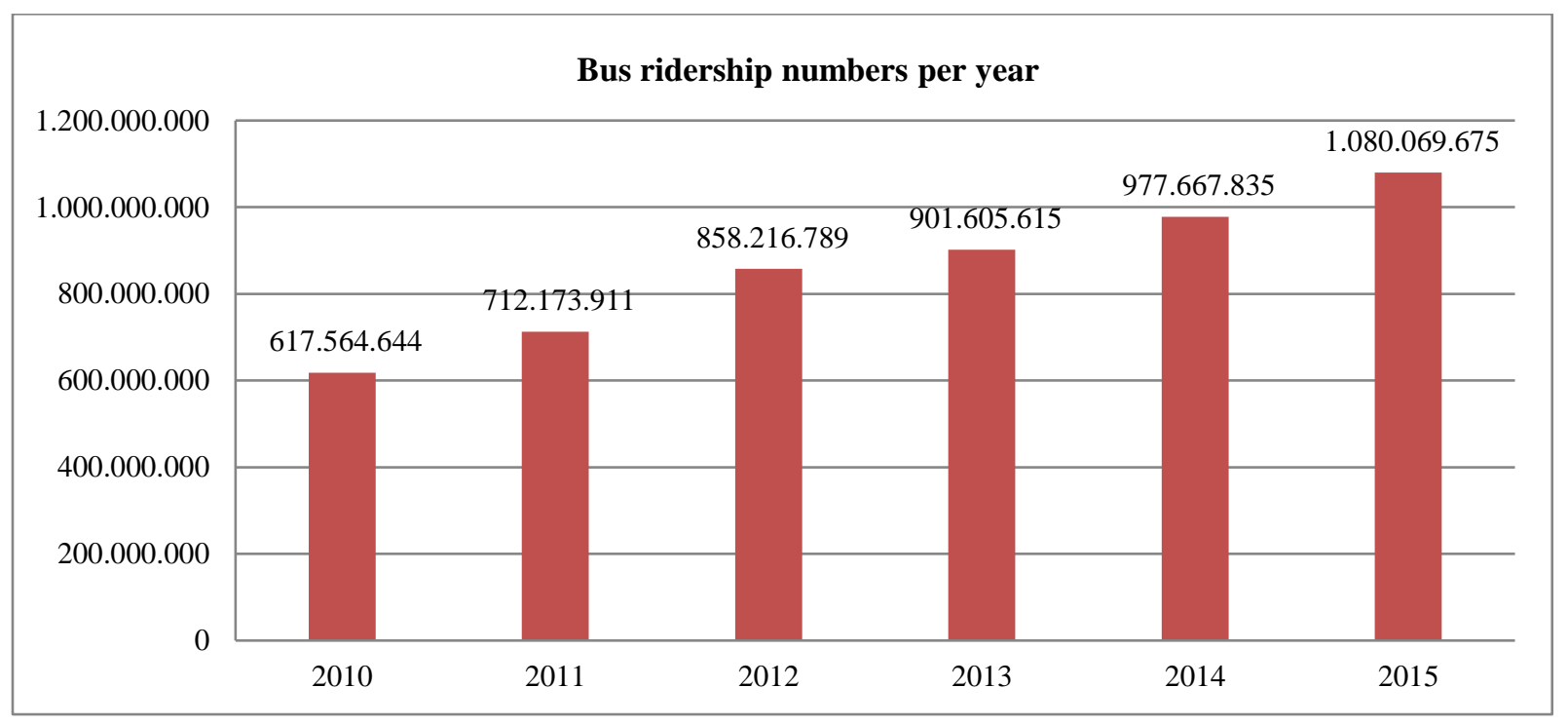

Figure 4. Number of IETT's bus journeys by years.

Considering the fact that the annual population growth rate of Istanbul is around $2.7 \%$ and the population will be increasing with the same speed in the next few years, it is estimated that the total growth rate will reach $14.25 \%$ in five years [44]. In line with the goal of extending the length of rail network from $142.15 \mathrm{~km}$ (as of March 2016) to $420 \mathrm{~km}$ by the end of 2019 , it is expected that road transportation networks feeding the rail network will also play a more active role [45].

\subsubsection{Public transport firms in Istanbul}

In Istanbul, there are 2 operators responsible for delivering bus, BRT and rail services; namely IETT and Metro Istanbul.

IETT is the public bus operator and authority in Istanbul, responsible for providing and 
monitoring bus and BRT services in Istanbul, a city of nearly 15 million population. IETT is a public company operating under IMM. IETT currently has nearly 8000 staff including drivers, maintenance staff, and white collar workers like engineers, and officers. Besides, it has 3059 buses and 10 bus depots. It operates more than 700 routes within the city boundaries. It also monitors nearly 3500 buses, operated by private bus companies [43].

IETT also provides BRT services, carrying nearly 900.000 passengers daily. BRT provides totally segregated right-of-way for only BRT vehicles. BRT project was completed in 5 years with 4 phases. With a total of $52 \mathrm{~km}$ long dedicated BRT route, 45 stations, travel time is reduced 52 minutes, reduction of 623 tons of CO2/year, 242 tons of fuel savings/day are achieved.

Metro Istanbul is the subsidiary company of IMM providing rail services including heavy rail, light rail, metro funicular and tram services. Currently it operates $145 \mathrm{~km}$ of rail network is Istanbul, however until 2019 it will be operating $420 \mathrm{~km}$ of rail network when all the rail investments are completed. Rail network is the backbone of Istanbul's public transportation network and bus services are designed to feed this rail network. As rail services become more prioritized by IMM in terms of financial support, the service quality also shows an increase as reflected by the results of customer satisfaction surveys (CSS).

Customer satisfaction surveys provide a good indicator of the perceived quality of public transport providers' mobility services. The satisfaction of the customers also gives clues about the success and sustainability of the public transport companies. Designing categories and related questions are quite important to obtain results that can be turned into implementable actions. Using parameters like availability, accessibility, comfort etc. in the survey and preparing questions for each parameter is helpful to understand the perceived service quality. EN 13816 service quality criteria can be used for this purpose: availability, accessibility, time, information, customer service, comfort, safety, environmental impact.

\subsection{The Proposed Method Computations}

In this study, 6 experts participated in the evaluation of eight criteria. The linguistic assessments for the eight criteria are determined by the committee using rating scales (see Table 1). The experts were from the IETT (Istanbul Electricity, Tunnel and Tram Enterprises). Then, the fuzzy weights $\left(\widetilde{w}_{j}\right)$ for each criterion are computed by using Eq. (1). The fuzzy weights of the 8 criteria are presented in Table 3 . Based on experts' decisions, the weights of the top three criteria are determined as: $\mathrm{C}_{1}$ (Availability), $\mathrm{C}_{3}$ (Time) and $\mathrm{C}_{6}$ (Comfort). 6 experts from IETT assessed the 8 criteria and availability, time and comfort criteria stand out as the most important 3 criteria, respectively.

The questionnaire used in this study is applied to totally 323 passengers. The passengers evaluated the transport modes (metro, buses and BRT) according to each of the 8 criteria (using rating scales of Table 1). The fuzzy decision matrix for the alternatives is computed by using Eqs. (2-4) in Table 4. 
Table 3. Fuzzy weights for criteria.

\begin{tabular}{cl}
\hline Criteria & \multicolumn{1}{c}{ Weights } \\
\hline $\mathrm{C}_{1}$ & $((0.83 ; 0.97 ; 0.97 ; 1 ; 1 ; 1),(0.9 ; 0.97 ; 0.97 ; 0.98 ; 0.9 ; 0.9))$ \\
$\mathrm{C}_{2}$ & $((0.53 ; 0.72 ; 0.72 ; 0.85 ; 1 ; 1),(0.63 ; 0.72 ; 0.72 ; 0.78 ; 0.9 ; 0.9))$ \\
$\mathrm{C}_{3}$ & $((0.73 ; 0.9 ; 0.9 ; 0.98 ; 1 ; 1),(0.82 ; 0.9 ; 0.9 ; 0.94 ; 0.9 ; 0.9))$ \\
$\mathrm{C}_{4}$ & $((0.35 ; 0.53 ; 0.53 ; 0.72 ; 1 ; 1),(0.44 ; 0.53 ; 0.53 ; 0.63 ; 0.9 ; 0.9))$ \\
$\mathrm{C}_{5}$ & $((0.45 ; 0.62 ; 0.62 ; 0.77 ; 1 ; 1),(0.53 ; 0.62 ; 0.62 ; 0.69 ; 0.9 ; 0.9))$ \\
$\mathrm{C}_{6}$ & $((0.73 ; 0.88 ; 0.88 ; 0.97 ; 1 ; 1),(0.81 ; 0.88 ; 0.88 ; 0.93 ; 0.9 ; 0.9))$ \\
$\mathrm{C}_{7}$ & $((0.4 ; 0.6 ; 0.6 ; 0.78 ; 1 ; 1),(0.5 ; 0.6 ; 0.6 ; 0.69 ; 0.9 ; 0.9))$ \\
$\mathrm{C}_{8}$ & $((0.22 ; 0.4 ; 0.4 ; 0.6 ; 1 ; 1),(0.31 ; 0.4 ; 0.4 ; 0.5 ; 0.9 ; 0.9))$ \\
\hline
\end{tabular}

Table 4. The fuzzy decision matrix.

\begin{tabular}{|c|c|c|c|}
\hline Criteria & Metro & Buses & BRT \\
\hline $\mathrm{C}_{1}$ & $((4.87 ; 4.87 ; 6.51 ; 7.86 ; 1 ; 1),(5.69 ; 6.51 ; 6.51 ; 7.19 ; 0.9 ; 0.9))$ & $((3.55 ; 3.55 ; 5.12 ; 6.7 ; 1 ; 1),(4.33 ; 5.12 ; 5.12 ; 5.91 ; 0.9 ; 0.9))$ & $((4.18 ; 4.18 ; 5.72 ; 7.12 ; 1 ; 1),(4.95 ; 5.72 ; 5.72 ; 6.42 ; 0.9 ; 0.9))$ \\
\hline $\mathrm{C}_{2}$ & $((5.11 ; 6.72 ; 6.72 ; 7.97 ; 1 ; 1),(5.92 ; 6.72 ; 6.72 ; 7.35 ; 0.9 ; 0.9))$ & $((4.11 ; 5.59 ; 5.59 ; 6.98 ; 1 ; 1),(4.85 ; 5.59 ; 5.59 ; 6.28 ; 0.9 ; 0.9))$ & $((4.22 ; 5.76 ; 5.76 ; 7.14 ; 1 ; 1),(4.99 ; 5.76 ; 5.76 ; 6.45 ; 0.9 ; 0.9))$ \\
\hline $\mathrm{C}_{3}$ & $((4.72 ; 6.18 ; 6.18 ; 7.38 ; 1 ; 1),(5.45 ; 6.18 ; 6.18 ; 6.78 ; 0.9 ; 0.9))$ & $((4.58 ; 6.13 ; 6.13 ; 7.43 ; 1 ; 1),(5.36 ; 6.13 ; 6.13 ; 6.78 ; 0.9 ; 0.9))$ & $((4.33 ; 5.99 ; 5.99 ; 7.45 ; 1 ; 1),(5.16 ; 5.99 ; 5.99 ; 6.72 ; 0.9 ; 0.9))$ \\
\hline $\mathrm{C}_{4}$ & $((4.96 ; 6.37 ; 6.37 ; 7.5 ; 1 ; 1),(5.66 ; 6.37 ; 6.37 ; 6.93 ; 0.9 ; 0.9))$ & $((4.59 ; 6.08 ; 6.08 ; 7.35 ; 1 ; 1),(5.33 ; 6.08 ; 6.08 ; 6.72 ; 0.9 ; 0.9))$ & $((4.24 ; 5.8 ; 5.8 ; 7.2 ; 1 ; 1),(5.02 ; 5.8 ; 5.8 ; 6.5 ; 0.9 ; 0.9))$ \\
\hline $\mathrm{C}_{s}$ & $((5.07 ; 6.6 ; 6.6 ; 7.8 ; 1 ; 1),(5.83 ; 6.6 ; 6.6 ; 7.2 ; 0.9 ; 0.9))$ & $((4.98 ; 6.51 ; 6.51 ; 7.75 ; 1 ; 1),(5.75 ; 6.51 ; 6.51 ; 7.13 ; 0.9 ; 0.9))$ & $((4.27 ; 5.75 ; 5.75 ; 7.1 ; 1 ; 1),(5.01 ; 5.75 ; 5.75 ; 6.43 ; 0.9 ; 0.9))$ \\
\hline $\mathrm{C}_{\text {s }}$ & $((4.33 ; 5.87 ; 0 ; 7.2 ; 1 ; 1),(5.1 ; 5.87 ; 5.87 ; 6.54 ; 0.9 ; 0.9))$ & $((4.16 ; 5.73 ; 0 ; 7.13 ; 1 ; 1),(4.95 ; 5.73 ; 5.73 ; 6.43 ; 0.9 ; 0.9))$ & $((4.11 ; 5.69 ; 0 ; 7.11 ; 1 ; 1),(4.9 ; 5.69 ; 5.69 ; 6.4 ; 0.9 ; 0.9))$ \\
\hline $\mathrm{C}_{\mathrm{s}}$ & $((4.89 ; 6.3 ; 6.3 ; 7.43 ; 1 ; 1),(5.59 ; 6.3 ; 6.3 ; 6.87 ; 0.9 ; 0.9))$ & $((4.59 ; 6.22 ; 6.22 ; 7.61 ; 1 ; 1),(5.41 ; 6.22 ; 6.22 ; 6.91 ; 0.9 ; 0.9))$ & $((4.46 ; 6.01 ; 6.01 ; 7.33 ; 1 ; 1),(5.23 ; 6.01 ; 6.01 ; 6.67 ; 0.9 ; 0.9))$ \\
\hline
\end{tabular}

Table 5. The fuzzy normalized decision matrix.

\begin{tabular}{|c|c|c|c|}
\hline Criteria & Metro & Buses & BRT \\
\hline $\mathrm{C}_{1}$ & $((0.62 ; 0.62 ; 0.83 ; 1 ; 1 ; 1),(0.72 ; 0.83 ; 0.83 ; 0.91 ; 0.9 ; 0.9))$ & $((0.45 ; 0.45 ; 0.65 ; 0.85 ; 1 ; 1),(0.55 ; 0.65 ; 0.65 ; 0.75 ; 0.9 ; 0.9))$ & $((0.53 ; 0.53 ; 0.73 ; 0.91 ; 1 ; 1),(0.63 ; 0.73 ; 0.73 ; 0.82 ; 0.9 ; 0.9))$ \\
\hline $\mathrm{C}_{2}$ & $((0.64 ; 0.84 ; 0.84 ; 1 ; 1 ; 1),(0.74 ; 0.84 ; 0.84 ; 0.92 ; 0.9 ; 0.9))$ & $((0.52 ; 0.7 ; 0.7 ; 0.87 ; 1 ; 1),(0.61 ; 0.7 ; 0.7 ; 0.79 ; 0.9 ; 0.9))$ & $((0.53 ; 0.72 ; 0.72 ; 0.9 ; 1 ; 1),(0.63 ; 0.72 ; 0.72 ; 0.81 ; 0.9 ; 0.9))$ \\
\hline $\mathrm{C}_{3}$ & $((0.63 ; 0.83 ; 0.83 ; 0.99 ; 1 ; 1),(0.73 ; 0.83 ; 0.83 ; 0.91 ; 0.9 ; 0.9))$ & $((0.62 ; 0.82 ; 0.82 ; 1 ; 1 ; 1),(0.72 ; 0.82 ; 0.82 ; 0.91 ; 0.9 ; 0.9))$ & $((0.58 ; 0.8 ; 0.8 ; 1 ; 1 ; 1),(0.69 ; 0.8 ; 0.8 ; 0.9 ; 0.9 ; 0.9))$ \\
\hline $\mathrm{C}_{4}$ & $((0.66 ; 0.85 ; 0.85 ; 1 ; 1 ; 1),(0.76 ; 0.85 ; 0.85 ; 0.93 ; 0.9 ; 0.9))$ & $((0.61 ; 0.81 ; 0.81 ; 0.98 ; 1 ; 1),(0.71 ; 0.81 ; 0.81 ; 0.9 ; 0.9 ; 0.9))$ & $((0.57 ; 0.77 ; 0.77 ; 0.96 ; 1 ; 1),(0.67 ; 0.77 ; 0.77 ; 0.87 ; 0.9 ; 0.9))$ \\
\hline $\mathrm{C}_{5}$ & $((0.65 ; 0.85 ; 0.85 ; 1 ; 1 ; 1),(0.75 ; 0.85 ; 0.85 ; 0.92 ; 0.9 ; 0.9))$ & $((0.64 ; 0.83 ; 0.83 ; 0.99 ; 1 ; 1),(0.74 ; 0.83 ; 0.83 ; 0.91 ; 0.9 ; 0.9))$ & $((0.55 ; 0.74 ; 0.74 ; 0.91 ; 1 ; 1),(0.64 ; 0.74 ; 0.74 ; 0.82 ; 0.9 ; 0.9))$ \\
\hline C. & $((0.6 ; 0.81 ; 0 ; 1 ; 1 ; 1),(0.71 ; 0.81 ; 0.81 ; 0.91 ; 0.9 ; 0.9))$ & $((0.58 ; 0.8 ; 0 ; 0.99 ; 1 ; 1),(0.69 ; 0.8 ; 0.8 ; 0.89 ; 0.9 ; 0.9))$ & $((0.57 ; 0.79 ; 0 ; 0.99 ; 1 ; 1),(0.68 ; 0.79 ; 0.79 ; 0.89 ; 0.9 ; 0.9))$ \\
\hline $\mathrm{C}_{s}$ & $((0.64 ; 0.83 ; 0.83 ; 0.98 ; 1 ; 1),(0.74 ; 0.83 ; 0.83 ; 0.9 ; 0.9 ; 0.9))$ & $((0.6 ; 0.82 ; 0.82 ; 1 ; 1 ; 1),(0.71 ; 0.82 ; 0.82 ; 0.91 ; 0.9 ; 0.9))$ & $((0.59 ; 0.79 ; 0.79 ; 0.96 ; 1 ; 1),(0.69 ; 0.79 ; 0.79 ; 0.88 ; 0.9 ; 0.9))$ \\
\hline
\end{tabular}

Table 6. The fuzzy weighted normalized decision matrix.

\begin{tabular}{cllll}
\hline Criteria & \multicolumn{1}{c}{ Metro } & \multicolumn{1}{c}{ Buses } & \multicolumn{1}{c}{ BRT } \\
\hline $\mathrm{C}_{1}$ & $((0.52 ; 0.6 ; 0.8 ; 1 ; 1 ; 1),(0.65 ; 0.8 ; 0.8 ; 0.9 ; 0.9 ; 0.9))$ & $((0.38 ; 0.44 ; 0.63 ; 0.85 ; 1 ; 1),(0.5 ; 0.63 ; 0.63 ; 0.74 ; 0.9 ; 0.9))$ & $((0.44 ; 0.51 ; 0.7 ; 0.91 ; 1 ; 1),(0.57 ; 0.7 ; 0.7 ; 0.8 ; 0.9 ; 0.9))$ \\
$\mathrm{C}_{2}$ & $((0.34 ; 0.6 ; 0.6 ; 0.85 ; 1 ; 1),(0.46 ; 0.6 ; 0.6 ; 0.72 ; 0.9 ; 0.9))$ & $((0.28 ; 0.5 ; 0.5 ; 0.74 ; 1 ; 1),(0.38 ; 0.5 ; 0.5 ; 0.62 ; 0.9 ; 0.9))$ & $((0.28 ; 0.52 ; 0.52 ; 0.76 ; 1 ; 1),(0.39 ; 0.52 ; 0.52 ; 0.63 ; 0.9 ; 0.9))$ \\
$\mathrm{C}_{3}$ & $((0.46 ; 0.75 ; 0.75 ; 0.97 ; 1 ; 1),(0.6 ; 0.75 ; 0.75 ; 0.86 ; 0.9 ; 0.9))$ & $((0.45 ; 0.74 ; 0.74 ; 0.98 ; 1 ; 1),(0.59 ; 0.74 ; 0.74 ; 0.86 ; 0.9 ; 0.9))$ & $((0.43 ; 0.72 ; 0.72 ; 0.98 ; 1 ; 1),(0.57 ; 0.72 ; 0.72 ; 0.85 ; 0.9 ; 0.9))$ \\
$\mathrm{C}_{4}$ & $((0.23 ; 0.45 ; 0.45 ; 0.72 ; 1 ; 1),(0.33 ; 0.45 ; 0.45 ; 0.58 ; 0.9 ; 0.9))$ & $((0.21 ; 0.43 ; 0.43 ; 0.7 ; 1 ; 1),(0.31 ; 0.43 ; 0.43 ; 0.56 ; 0.9 ; 0.9))$ & $((0.2 ; 0.41 ; 0.41 ; 0.69 ; 1 ; 1),(0.3 ; 0.41 ; 0.41 ; 0.54 ; 0.9 ; 0.9))$ \\
$\mathrm{C}_{5}$ & $((0.29 ; 0.52 ; 0.52 ; 0.77 ; 1 ; 1),(0.4 ; 0.52 ; 0.52 ; 0.64 ; 0.9 ; 0.9))$ & $((0.29 ; 0.51 ; 0.51 ; 0.76 ; 1 ; 1),(0.39 ; 0.51 ; 0.51 ; 0.63 ; 0.9 ; 0.9))$ & $((0.25 ; 0.45 ; 0.45 ; 0.7 ; 1 ; 1),(0.34 ; 0.45 ; 0.45 ; 0.57 ; 0.9 ; 0.9))$ \\
$\mathrm{C}_{6}$ & $((0.44 ; 0.72 ; 0 ; 0.97 ; 1 ; 1),(0.57 ; 0.72 ; 0.72 ; 0.84 ; 0.9 ; 0.9))$ & $((0.42 ; 0.7 ; 0 ; 0.96 ; 1 ; 1),(0.56 ; 0.7 ; 0.7 ; 0.83 ; 0.9 ; 0.9))$ & $((0.42 ; 0.7 ; 0 ; 0.95 ; 1 ; 1),(0.55 ; 0.7 ; 0.7 ; 0.82 ; 0.9 ; 0.9))$ \\
$\mathrm{C}_{3}$ & $((0.25 ; 0.5 ; 0.5 ; 0.78 ; 1 ; 1),(0.36 ; 0.5 ; 0.5 ; 0.63 ; 0.9 ; 0.9))$ & $((0.24 ; 0.48 ; 0.48 ; 0.77 ; 1 ; 1),(0.35 ; 0.48 ; 0.48 ; 0.61 ; 0.9 ; 0.9))$ & $((0.21 ; 0.43 ; 0.43 ; 0.72 ; 1 ; 1),(0.31 ; 0.43 ; 0.43 ; 0.57 ; 0.9 ; 0.9))$ \\
$\mathrm{C}_{5}$ & $((0.14 ; 0.33 ; 0.33 ; 0.59 ; 1 ; 1),(0.23 ; 0.33 ; 0.33 ; 0.45 ; 0.9 ; 0.9))$ & $((0.13 ; 0.33 ; 0.33 ; 0.6 ; 1 ; 1),(0.22 ; 0.33 ; 0.33 ; 0.45 ; 0.9 ; 0.9))$ & $((0.13 ; 0.32 ; 0.32 ; 0.58 ; 1 ; 1),(0.21 ; 0.32 ; 0.32 ; 0.44 ; 0.9 ; 0.9))$ \\
\hline
\end{tabular}


Table 7. The ranking value $\operatorname{Rank} \tilde{A}_{i}$ of the trapezoidal interval type-2 fuzzy set.

\begin{tabular}{rccccc}
\hline Criteria & Metro & Buses & BRT & PIS & NIS \\
\hline $\mathrm{C}_{1}$ & 8.102 & 7.140 & 7.566 & 8.102 & 7.140 \\
$\mathrm{C}_{2}$ & 7.233 & 6.660 & 6.743 & 7.233 & 6.660 \\
$\mathrm{C}_{3}$ & 7.777 & 7.744 & 7.648 & 7.777 & 7.648 \\
$\mathrm{C}_{4}$ & 6.378 & 6.259 & 6.147 & 6.378 & 6.147 \\
$\mathrm{C}_{5}$ & 6.772 & 6.734 & 6.392 & 6.772 & 6.392 \\
$\mathrm{C}_{6}$ & 6.958 & 6.883 & 6.859 & 6.958 & 6.859 \\
$\mathrm{C}_{7}$ & 6.613 & 6.523 & 6.262 & 6.613 & 6.262 \\
$\mathrm{C}_{8}$ & 5.674 & 5.651 & 5.587 & 5.674 & 5.587 \\
\hline
\end{tabular}

Table 8. The grey relational coefficient values.

\begin{tabular}{cccccccc}
\hline \multirow{2}{*}{ Criteria } & Positive GRC & & & \multicolumn{2}{l}{ Negative GRC } \\
\cline { 2 - 3 } & Metro & Buses & BRT & & Metro & Buses & BRT \\
\hline $\mathrm{C}_{1}$ & 1.000 & 0.333 & 0.473 & & 0.333 & 1.000 & 0.531 \\
$\mathrm{C}_{2}$ & 1.000 & 0.333 & 0.369 & & 0.333 & 1.000 & 0.775 \\
$\mathrm{C}_{3}$ & 1.000 & 0.659 & 0.333 & & 0.333 & 0.403 & 1.000 \\
$\mathrm{C}_{4}$ & 1.000 & 0.494 & 0.333 & & 0.333 & 0.506 & 1.000 \\
$\mathrm{C}_{5}$ & 1.000 & 0.835 & 0.333 & & 0.333 & 0.357 & 1.000 \\
$\mathrm{C}_{6}$ & 1.000 & 0.399 & 0.333 & & 0.333 & 0.668 & 1.000 \\
$\mathrm{C}_{7}$ & 1.000 & 0.661 & 0.333 & & 0.333 & 0.402 & 1.000 \\
$\mathrm{C}_{8}$ & 1.000 & 0.652 & 0.333 & & 0.333 & 0.405 & 1.000 \\
\hline
\end{tabular}

Next step is computed by the fuzzy normalized decision matrix of alternatives using Eqs. (5)-(7). The fuzzy normalized decision matrix for the three alternatives is presented in Table 5. The second weight of each criterion weighted normalized fuzzy decision matrix is found in Table 6. This matrix is computed by Eq. (8). The positive and the negative-ideal solutions are computed by using Eqs. (9)-(12). Table 7 shows the results of this step. Next, the grey relational coefficient (GRC) values between each alternative and other compared alternatives are computed using Eq. (13), as shown in Table 8. Here, the resolving coefficient $\zeta=0.5$ is used to solve fuzzy grey relational coefficient. The grey relational coefficient of each alternative from PIS and NIS is computed by Eqs. (14)-(15).
Subsequently, $S_{i}$ and $R_{i}$ of each alternative is computed by Eq. (16) and $Q_{i}$ values calculated by Eq. (17). Finally, the values of each alternative for final ranking are shown in Table 9. That means that $A_{1}$ is preferred over $A_{2}$ and $A_{3}$.

Table 9. Ranking of alternatives according to $Q_{i}$ index $(\zeta$ $=0.5$ ).

\begin{tabular}{lcccc}
\hline Alternatives & $\mathrm{S}_{\mathrm{i}}$ & $\mathrm{R}_{\mathrm{i}}$ & $\mathrm{Q}_{\mathrm{i}}(v=0.5)$ & Ranking \\
\hline $\mathrm{A}_{1}$ (Metro) & 8.000 & 0.333 & 0.000 & 1 \\
$\mathrm{~A}_{2}$ (Buses) & 4.366 & 1.000 & 0.852 & 2 \\
$\mathrm{~A}_{3}$ (BRT/Metrobus) & 2.842 & 1.000 & 1.000 & 3 \\
\hline
\end{tabular}

Comparison of Metro, Buses, and BRT respectively is shown in Fig. 5. Metro is the best among the three alternatives because it has the smallest $Q_{i}$, while BRT is the worst alternative. 


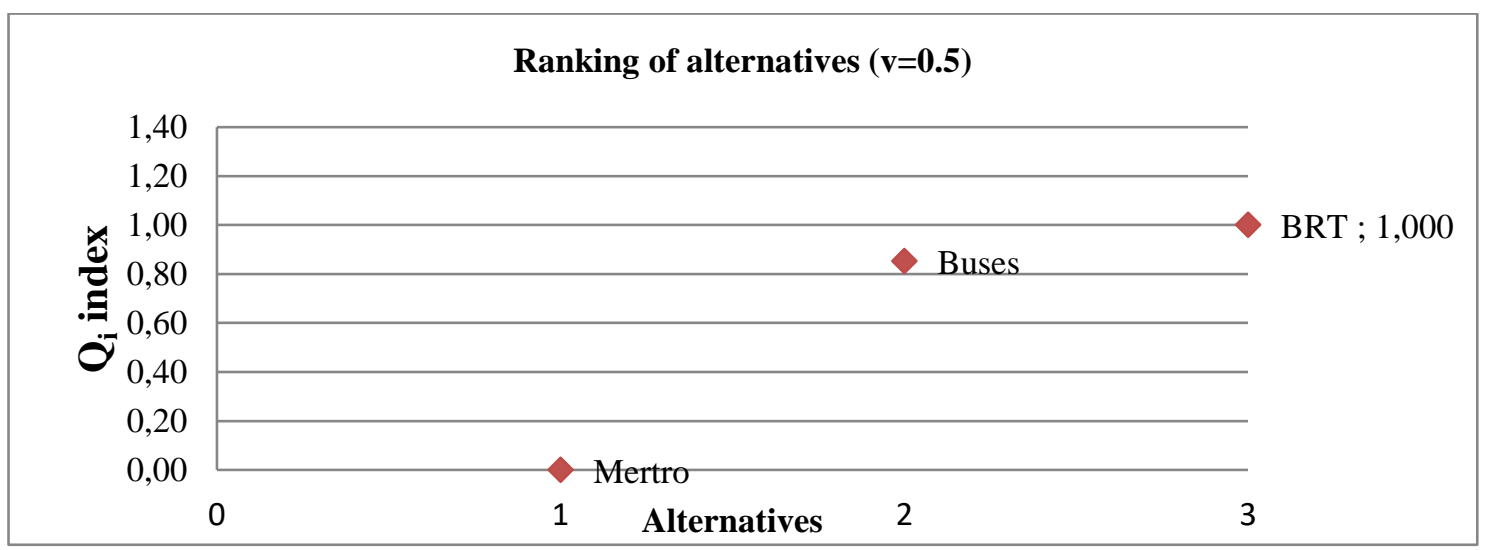

Figure 5. Ranking the evaluated alternative.

\subsection{Sensitivity Analysis}

This study uses the concept of sensitivity analysis to examine the proposed method in order to demonstrate that the proposed approach is appropriate for a range of values [36]. Here, we will use each resolving coefficient value $\zeta$ whether they will affect the results of the ranking order of the alternatives by using the proposed method. The resolving coefficient values between $\zeta=0.1$ and $\zeta=1$ are used to examine the proposed method. During analysis process it is observed that, various resolving coefficient values do not affect the ranking order of the alternatives. After considering the results of the sensitivity analysis, shown in Fig. 6, alternative $A_{l}$ (Metro) is still the best alternative among 10 experiments. The details of these 10 experiments are presented in Table 10.

Table 10. The $Q_{i}$ value of each the public transportation firms by using each resolving coefficient value and each $\zeta$ value.

\begin{tabular}{cccccccccc}
\hline & Alternatives & $\mathrm{S}_{\mathrm{i}}$ & $\mathrm{R}_{\mathrm{i}}$ & $\mathrm{Q}_{\mathrm{i}}$ & & Alternatives & $\mathrm{d}^{*}$ & $\mathrm{~d}^{-}$ & $\mathrm{CC}_{\mathrm{i}}$ \\
\hline$\zeta=0.1$ & $\mathrm{~A}_{1}$ & 8.00 & 0.33 & 0.00 & $\zeta=0.6$ & $\mathrm{~A}_{1}$ & 8.00 & 0.33 & 0.00 \\
& $\mathrm{~A}_{2}$ & 4.37 & 1.00 & 0.97 & & $\mathrm{~A}_{2}$ & 4.37 & 1.00 & 0.82 \\
& $\mathrm{~A}_{3}$ & 2.84 & 1.00 & 1.00 & & $\mathrm{~A}_{3}$ & 2.84 & 1.00 & 1.00 \\
& & & & & & & & & \\
& $\mathrm{~A}_{1}$ & 8.00 & 0.33 & 0.00 & $\zeta=0.7$ & $\mathrm{~A}_{1}$ & 8.00 & 0.33 & 0.00 \\
& $\mathrm{~A}_{2}$ & 4.37 & 1.00 & 0.94 & & $\mathrm{~A}_{2}$ & 4.37 & 1.00 & 0.79 \\
& $\mathrm{~A}_{3}$ & 2.84 & 1.00 & 1.00 & & $\mathrm{~A}_{3}$ & 2.84 & 1.00 & 1.00 \\
& & & & & & & & \\
& $\mathrm{~A}_{1}$ & 8.00 & 0.33 & 0.00 & $\zeta=0.8$ & $\mathrm{~A}_{1}$ & 8.00 & 0.33 & 0.00 \\
& $\mathrm{~A}_{2}$ & 4.37 & 1.00 & 0.91 & & $\mathrm{~A}_{2}$ & 4.37 & 1.00 & 0.76 \\
& $\mathrm{~A}_{3}$ & 2.84 & 1.00 & 1.00 & & $\mathrm{~A}_{3}$ & 2.84 & 1.00 & 1.00 \\
& & & & & & & & \\
& $\mathrm{~A}_{1}$ & 8.00 & 0.33 & 0.00 & $\zeta=0.9$ & $\mathrm{~A}_{1}$ & 8.00 & 0.33 & 0.00 \\
& $\mathrm{~A}_{2}$ & 4.37 & 1.00 & 0.88 & & $\mathrm{~A}_{2}$ & 4.37 & 1.00 & 0.73 \\
& $\mathrm{~A}_{3}$ & 2.84 & 1.00 & 1.00 & & $\mathrm{~A}_{3}$ & 2.84 & 1.00 & 1.00 \\
& & & & & & & & \\
& $\mathrm{~A}_{1}$ & 8.00 & 0.33 & 0.00 & $\zeta=1$ & $\mathrm{~A}_{1}$ & 8.00 & 0.33 & 0.00 \\
& $\mathrm{~A}_{2}$ & 4.37 & 1.00 & 0.85 & & $\mathrm{~A}_{2}$ & 4.37 & 1.00 & 0.70 \\
& $\mathrm{~A}_{3}$ & 2.84 & 1.00 & 1.00 & & $\mathrm{~A}_{3}$ & 2.84 & 1.00 & 1.00 \\
\hline
\end{tabular}




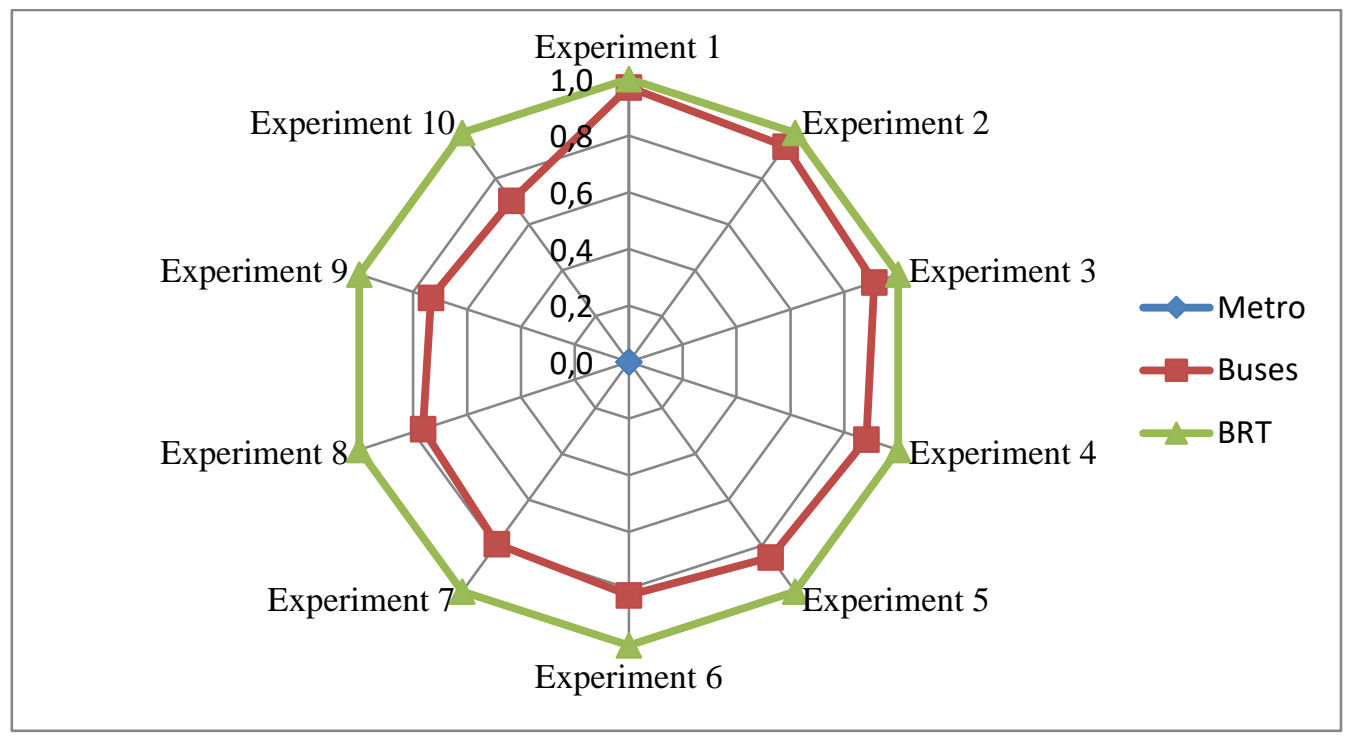

Figure 6. Sensitivity analysis of $Q_{i}$ values for each alternative.

\subsection{Comparison of results from the MCDM methods}

The evaluation of the problem can be addressed by applying the interval type-2 fuzzy TOPSIS method and final ranking shown in Table 11.

Table 11. Ranking of the public transportation firms according to closeness coefficients $\left(\mathrm{CC}_{\mathrm{i}}\right)$.

\begin{tabular}{lcccc}
\hline Alternatives & $\mathrm{D}^{*}$ & $\mathrm{D}-$ & $\mathrm{CC}_{\mathrm{i}}$ & Ranking \\
\hline Metro & 0.00 & 2.84 & 1.000 & 1 \\
Buses & 1.93 & 0.91 & 0.320 & 2 \\
BRT/Metrobus & 2.32 & 0.51 & 0.182 & 3 \\
\hline
\end{tabular}

The results from the proposed integrated interval type-2 fuzzy MCDM methods are provided in Table 12. The ranking of each of the different routes obtained from interval type-2 fuzzy TOPSIS is Metro > Buses > BRT, and similarly Metro > Buses > BRT is also obtained by the integrated interval type-2 fuzzy VIKOR based on TOPSIS and GRA. The proposed approach can be useful for researchers in the selection of methods.

Table 12. The result of proposed methodologies.

\begin{tabular}{ccc}
\hline Alternatives & $\begin{array}{c}\text { Interval type-2 Fuzzy } \\
\text { TOPSIS (IT2FT) }\end{array}$ & $\begin{array}{c}\text { Interval type-2 Fuzzy } \\
\text { TOPSIS and GRA based VIKOR (IT2FTGV) }\end{array}$ \\
\hline Metro & 1 & 1 \\
Buses & 2 & 2 \\
BRT/Metrobus & 3 & 3 \\
\hline
\end{tabular}

\section{FINDINGS}

Istanbul Metropolitan Municipality (IMM), which is the ultimate authority for delivering public transportation services, recently prioritized the rail investments. Until 2019, IMM aims to increase the currently $145 \mathrm{~km}$ of rail network to
$420 \mathrm{~km}$. As rail transportation becomes the main transport mode in Istanbul and attracts substantial financial resources to increase its quality, this is reflected in the results of CSS. People find the reliability, accessibility and comfort levels of metro services higher than BRT or bus services. 
Since metro has a higher capacity than bus or BRT services, it can handle higher number of people in a comfortable way. Due to BRT overcrowding and capacity problems, CSS scored lowest in this mode. According to the CSS results, comfort, safety and environmental impact of BRT are low-satisfaction areas. By improving on these areas, it is possible to increase CSS score for BRT.

The reason why BRT has the lowest CSS score can be attributed to the fact that during peak hours BRT has huge demand which cannot be met with current capacity. BRT carries nearly 900.000 passengers daily and this creates some comfort problems especially during peak hours. Even if BRT reduces the travel times in the most heavily congested corridor of Istanbul, this might not be enough to compensate for the lack of comfort in peak hours. Safety issues and environmental impact are also open to improvement.

Bus services generally play a complementary role to feed main metro and BRT network. However, the high traffic congestion levels on the road make it quite hard to provide reliable and on time bus services. Since people regard reliability as one of the most important quality criteria, buses' having lower satisfaction scores compared to metro services is understandable. Suffering from long travel times and low comfort levels in buses because of high passenger volumes can be regarded as the main reasons behind the low satisfaction scores. Information and environmental impact are also serious concerns from the perspective of passengers. With regard to information, integration with other modes is quite important to provide a multi-modal information services to passengers. Environmental impact can be further reduced by introducing more environmentally friendly fuel types like electricity, CNG or hybrid.

According to the study results $\mathrm{C}_{1}$ (Availability), $\mathrm{C}_{3}$ (Time) and $\mathrm{C}_{6}$ (Comfort) are the most important criteria for passengers, whereas $\mathrm{C}_{8}$ (Environmental impact), $\mathrm{C}_{4}$ (Information) and $\mathrm{C}_{7}$ (Safety)are regarded as the least important criteria.

Availability is influenced by the following factors:

- Distance to boarding/alighting points

- Need for transfers

- Area covered by the current route network

- Operating hours

- Frequency

- Operating Load Factor

- Suitability

- Dependability

Any improvement with regard to the above factors will increase the availability of the services.

Time is affected by the following factors:

- Length of trip time

- Adherence to schedule (punctuality and regularity)

As people expect reliable services in terms of punctuality and regularity, which is already problematic in Istanbul's public transportation system, this expectation is quite understandable. Lastly, comfort is influenced by the following factors:

- Usability of passenger facilities

- Seating and personal space

- Ride comfort

- Ambient conditions

- Complementary facilities

- Ergonomics

Here, if the overcrowding in public transport modes can be reduced in such a way to provide a pleasurable and comfortable service, then satisfaction with comfort will increase significantly. 


\section{CONCLUSION}

This study presents the use of interval type-2 fuzzy MCDM methods based on TOPSIS, GRA and VIKOR to assess the public transportation firms and their satisfaction levels are evaluated by using customer satisfaction survey. When comparing with type-1 fuzzy sets, interval type-2 fuzzy set can better reflect uncertainty of inaccurate information. Therefore, a type-2 fuzzy MCDM method is proposed, to evaluate and improve customer satisfaction in public transportation firms. Then, the criteria which need to be improved are determined. The results show that IT2FTGV approach is a useful tool for decision makers in the evaluation of public transportation firms.

This study can be of help for those who want to examine customer satisfaction levels for public transportation firms. As for the proposed method, the performance of IT2FTGV can be compared with different fuzzy decision making approaches such as hesitant fuzzy set theory based methodologies. The scope of application of the MCDM method is not limited by the evaluation of public transportation, it may also be applied in areas such as service evaluation, transport personnel selection, human resource management, staff recruitment and performance assessment.

\section{REFERENCES}

[1]. Evren G., Ulaştırma Planlamasında Gelişmekte Olan Ülkelere Özgü Sorunlar. 3. Ulaştırma Kongresi, 1995, 11-24.

[2]. Tang K. X., Waters N. M., The internet, GIS and public participation in transportation planning. Progress in Planning, 64 (2005) 7-62.

[3]. Turan M., Kent İçi Ulaşımın Enerji Tasarrufu Üzerindeki Olası Etkileri, Yüksek Lisans Tezi, Gazi Üniversitesi
Sosyal Bilimler Enstitüsü Uluslararas1 İktisat Bilim Dalı, Ankara, 1998.

[4]. Litman T., Valuing transit service quality improvements. Journal of Public transportation. 11 (2008) 43-63.

[5]. APTA, Public Transportation: Benefits for 21st Century. American Public Transport Association Report, 2007, Washington, DC.

[6]. Belbag S., Deveci M., Uludag A. S., Comparison of Two Fuzzy Multi Criteria Decision Methods for Potential Airport Location Selection. In ICORES, 2013, 270276.

[7]. Yavuz S., Deveci M., Bulanik TOPSIS ve Bulanik VIKOR Yöntemleriyle Alisveris Merkezi Kurulus Yeri Seçimi ve Bir Uygulama/Selection of Shopping Center Location with The Methods of Fuzzy VIKOR and Fuzzy TOPSIS and An Application. Ege Akademik Bakis, 14 (2014): 463.

[8]. Deveci M., Demirel N. Ç., John R., Özcan E., Fuzzy multi-criteria decision making for carbon dioxide geological storage in Turkey. Journal of Natural Gas Science and Engineering, 27 (2015) 692-705.

[9]. Demirel N. Ç., Deveci M., Eser G., Comparative analysis of fuzzy multicriteria decision making for location selection of Textile plant in Turkey. In Proceedings of International Academic Conferences (No. 4006524). International Institute of Social and Economic Sciences, 2016.

[10]. Deveci M., Demirel N. Ç., Ahmetoğlu E., Airline new route selection based on interval type-2 fuzzy MCDM: A case study of new route between Turkey-North American region destinations. Journal of Air Transport Management, 59 (2017) 8399.

[11]. Demirel, N. Ç., Demirel, T., Deveci, M., Vardar, G., Location selection for 
underground natural gas storage using Choquet integral. Journal of Natural Gas Science and Engineering, 45 (2017) 368379.

[12]. Deveci M., Özcan E., John R., Öner S. C., Interval type-2 hesitant fuzzy set method for improving the service quality of domestic airlines in Turkey. Journal of Air Transport Management. 69C (2018) 83-98.

[13]. Demirel T., Öner S. C., Tüzün S., Deveci M., Öner M., Demirel N. Ç., Choquet integral-based hesitant fuzzy decisionmaking to prevent soil erosion. Geoderma, 313 (2018) 276-289.

[14]. Gupta R., Srivastava B., Tamilselvam S., Making public transportation schedule information consumable for improved decision making. In 2012 15th International IEEE Conference on Intelligent Transportation Systems, 2012, 1862-1867.

[15]. Diab E. I., Badami M. G., El-Geneidy A. M., Bus transit service reliability and improvement strategies: Integrating the perspectives of passengers and transit agencies in North America. Transport Reviews, 35 (2015) 292-328.

[16]. Levner E., Ceder A., Elalouf A., Hadas Y., Shabtay D., Detection and improvement of deficiencies and failures in publictransportation networks using agentenhanced distribution data mining. In Industrial Engineering and Engineering Management (IEEM), 2011 IEEE International Conference on-IEEE, 2011, 694-698.

[17]. Dias A., Telhada J., Carvalho M. S., A decision support system for a flexible transport system. ECEC-The European Concurrent Engineering, 1 (2011) 75-79.

[18]. Diab E. I., \& El-Geneidy A. M., 2012. Understanding the impacts of a combination of service improvement strategies on bus running time and passenger's perception. Transportation Research Part A: Policy and Practice, 46(2012) 614-625.

[19]. Mnif S., Galoui S., Elkosantini S., Darmoul S., Said L. B., Ontology based performance evaluation of public transport systems. In Advanced Logistics and Transport (ICALT), 2015 4th International Conference on -IEEE, 2015, 205-210.

[20]. Sadovnikova N., Parygin D., Kalinkina M., Sanzhapov B., Ni T. N., Models and Methods for the Urban Transit System Research. In Creativity in Intelligent, Technologies and Data Science. Springer International Publishing, 2015, 488-499.

[21]. Mokhtarian M. N., Sadi-Nezhad S., Makui A., A new flexible and reliable interval valued fuzzy VIKOR method based on uncertainty risk reduction in decision making process: An application for determining a suitable location for digging some pits for municipal wet waste landfill. Computers \& Industrial Engineering, 78 (2014) 213-233.

[22]. Gupta P., Mehlawat M. K., Grover N., Intuitionistic fuzzy multi-attribute group decision-making with an application to plant location selection based on a new extended VIKOR method. Information Sciences, 370 (2016) 184-203.

[23]. Vahdani B., Hadipour H., Sadaghiani J. S., Amiri, M., Extension of VIKOR method based on interval-valued fuzzy sets. The International Journal of Advanced Manufacturing Technology, 47 (9-12) (2010) 1231-1239.

[24]. Ghorabaee M. K., Developing an MCDM method for robot selection with interval type-2 fuzzy sets. Robotics and ComputerIntegrated Manufacturing, 37 (2016) 221232.

[25]. Qin J., Liu X., Pedrycz W., An extended VIKOR method based on prospect theory for multiple attribute decision making 
under interval type-2 fuzzy environment. Knowledge-Based Systems, 86 (2015) 116130.

[26]. Datta S., Samantra C., Mahapatra S. S., Banerjee S., Bandyopadhyay, A., Green supplier evaluation and selection using VIKOR method embedded in fuzzy expert system with interval-valued fuzzy numbers. International Journal of Procurement Management, 5 (2012) 647678.

[27]. You X. Y., You J. X., Liu H. C., Zhen L., Group multi-criteria supplier selection using an extended VIKOR method with interval 2-tuple linguistic information. Expert Systems with Applications, 42 (2015) 1906-1916.

[28]. Jahan A., Edwards K. L., VIKOR method for material selection problems with interval numbers and target-based criteria. Materials \& Design, 47 (2013) 759-765.

[29]. Liu H. C., Liu L., Wu J., Material selection using an interval 2-tuple linguistic VIKOR method considering subjective and objective weights. Materials \& Design, 52 (2013) 158-167.

[30]. Park J. H., Cho H. J., Kwun Y. C., Extension of the VIKOR method to dynamic intuitionistic fuzzy multiple attribute decision making. Computers \& Mathematics with Applications, 65 (2013) 731-744.

[31]. Chen S. M., Lee L. W., Fuzzy multiple attributes group decision-making based on the interval type-2 TOPSIS method. Expert systems with applications, 37 (2010) 27902798.

[32]. Hwang C.L., Yoon K., Multiple attributes decision making methods and applications. Springer, Berlin Heidelberg, 1981.

[33]. Chen C.T., Extensions of the TOPSIS for group decision-making under fuzzy environment. Fuzzy sets and systems, 114 (2000) 1-9.
[34]. Chen M. F., Tzeng G. H., Combining grey relation and TOPSIS concepts for selecting an expatriate host country. Mathematical and Computer Modelling, 40 (2004) 14731490.

[35]. Kuo M. S., Wu J. W., Pei L., A soft computing method for selecting evaluation criteria of service quality. Applied mathematics and computation, 189 (2007) 241-254.

[36]. Kuo M. S., A novel interval-valued fuzzy MCDM method for improving airlines' service quality in Chinese cross-strait airlines. Transportation Research Part E: Logistics and Transportation Review, 47 (2011) 1177-1193.

[37]. Kuo M. S., Liang G. S., Combining VIKOR with GRA techniques to evaluate service quality of airports under fuzzy environment. Expert Systems with Applications, 38 (2011) 1304-1312.

[38]. Wei G. W., Gray relational analysis method for intuitionistic fuzzy multiple attribute decision making. Expert systems with Applications, 38 (2011) 11671-11677.

[39]. Celik E., Bilisik O. N., Erdogan M., Gumus A. T., Baracli H., An integrated novel interval type-2 fuzzy MCDM method to improve customer satisfaction in public transportation for Istanbul. Transportation Research Part E: Logistics and Transportation Review, 58 (2013) 28-51.

[40]. Opricovic S., Multicriteria optimization of civil engineering systems. Faculty of Civil Engineering, 2 (1998) 5-21.

[41]. Opricovic S., Tzeng G.H., Compromise solution by MCDM methods: A comparative analysis of VIKOR and TOPSIS. European Journal of Operational Research, , 156 (2004) 445-455.

[42]. Opricovic S., Fuzzy VIKOR with an application to water resources planning. Expert Systems with Applications, 38 (2011) 12983-12990. 
[43]. http://www.iett.gov.tr

[44]. IETT, İstatistik Raporu, 2016, İstanbul.

[45]. IBB, 2015-2019 Stratejik Plan1, 2016,

[46]. İstanbul. http://www.ibb.gov.tr/trTR/kurumsal/Birimler/StratejikPlanlama Md/Documents/2010_2014/stratejikplan1 5_19.pdf
[47]. IETT, İstatistik Raporu, 2016, İstanbul. [48]. IBB, 2015-2019 Stratejik Plan1, 2016, İstanbul. http://www.ibb.gov.tr/trTR/kurumsal/Birimler/StratejikPlanlama Md/Documents/2010_2014/stratejikplan1 5_19.pdf 